IURNAL UPI

\title{
Teaching Preservation of Kemojo Cake (Bolu Kemojo) as A Traditional Cake of The Malay Community of Riau Province
}

Naufal Ashari*, Sudewi Yogha, Elly Lasmanawati

Program Studi Pendidikan Tata Boga, Universitas Pendidikan Indonesia, Bandung, Indonesia

Correspondence: E-mail: naoashari@upi.edu

\begin{abstract}
A B S T R A C T S
Kemojo cake is a traditional food of the Malay people from Riau Province. In ancient times, this cake was a snack for the king and guests of the Siak kingdom, which was located in Siak Regency, Riau Province. At that time, not everyone could enjoy the Kemojo Cake because it took a very long time to make. In ancient times, Kemojo Cake was always served at weddings, traditional events, and major Islamic events. The shape of Kemojo Cake holds the symbol of Frangipani flowers. Nowadays, it is not difficult to find Kemojo Cake because many sell it, especially in the city of Pekanbaru. Now, Kemojo Cake is sold with very interesting variations with different flavors and shape modifications. Because of that, preservation by remaking the original Kemojo Cake is very important. One of the objectives of the preservation is to maintain the original Kemojo Cake so that it will not be lost and so that it will get preserved by using observation, interview, and documentation techniques. Participants in this study were divided into 3 types: Kemojo Cake experts to find out about Kemojo Cake in-depth; Kemojo Cake businessmen to prove that Kemojo Cake had been modified both in terms of taste and shape, as well as to prove the greatness of the existence of Kemojo Cake in Riau Province; and local people who traditionally make Kemojo Cake as a form of conservation effort.
\end{abstract}

\begin{tabular}{l}
\hline \multicolumn{1}{c}{ A R T I C L E I N F O } \\
\hline Article History: \\
Submitted/Received 24 Jun 2021 \\
First revised $25 \mathrm{Jul} 2021$ \\
Accepted 08 Aug 2021 \\
First available online 13 Aug 2021 \\
Publication date 01 Sep 2021 \\
Keyword: \\
Kemojo Cake, \\
Malay, \\
Preservation, \\
Traditional.
\end{tabular}

\section{ARTICLE INFO}

First available online 13 Aug 202

Publication date 01 Sep 2021

Keyword:

Malay,

Traditional. 


\section{INTRODUCTION}

Indonesia is a country consisting of various tribes, these tribes have their own uniqueness, which are scattered throughout the islands in Indonesia. One of them is ethnic Malay in Riau province, here the Malay culture is very strong so that Riau province is dominated by ethnic Malays, especially in the city of Pekanbaru as the provincial capital. An ethnic group certainly has its own special food - each that can make the area famous, usually has a characteristic or specific that exists in the area, according to the tongue of the local community. An example is the cake "Bolu Kemojo" which is one of the traditional Riau cakes made from wheat flour.

The role of the government is very important in efforts to protect traditional food in an area, in this case the district/city (Rosmayanti, et al, 2019). Traditional food is now very rarely found because of the changing times. Some people think that traditional food is an outdated snack, so that now the food has been abandoned by the community, and has begun to switch to modern life. whereas traditional food is a form of ancestral heritage that must be maintained and preserved (Kusmaningttyas et al., 2013).

Chemojo cake is a type of traditional Riau food that was previously less well known because in ancient times this Kemojo cake or more often called Kemojo cake can only be enjoyed on certain occasions such as traditional ceremonies or weddings see Figure 1. In 1997, Mrs. Dinawati began to introduce and popularize this chemojo cake so that now it is no longer difficult to find this food when visiting the Riau area. Bolu chemojo is often also called sponge cake, which comes from the word frangipani or frangipani flowers. So called because the pan used to make this sponge has a shape like a frangipani flower. The people of Riau often make chemojo cake together because during traditional parties or traditional ceremonies, large amounts of chemojo cake are usually served. From here, it can be seen that mutual cooperation activities are inherited from their ancestors (Hartini \& Swasty, 2018). This cake is almost never absent during celebrations of traditional events in the area such as during feasts, weddings, and Eid. The texture is dense and tends to be like a wet cake, not like a soft sponge like cake. The taste is dominantly sweet with a slight aroma and taste of eggs when eaten. In addition to the original or original taste, now the kemojo sponge is also made with various flavors, such as durian, chocolate, dragon fruit, corn and others.

Due to the existence of this kemojo sponge, many people make variations of the taste of the chemojo cake by adding food flavors which are feared to change the authenticity of the chemojo cake in terms of taste, color and shape. The lack of public interest in the Kemojo cake with the original taste will be very influential even if this continues to happen it will result in the loss of the authenticity of the Kemojo cake which has been passed down from the ancestors of the Riau Malay community. This chemojo cake has a soft but not porous and dense inner texture, but a little dry on the outside, this is due to a unique processing method, chemojo cake is classified as a wet cake. Wet cake is a term used to describe a cake that is soft, tender and relatively wet. This type of cake usually has a short shelf life because of its high water content compared to other cakes. The shelf life of Bolu chemojo is only 2-3 days after it comes out of baking. In general, Kemojo sponge cake is made from wheat flour as the main ingredient, mixed with eggs, coconut milk, sugar and pandan leaves. The sale of chemojo cakes in the market now has many variations and flavors, of course, it will have an impact on the authenticity of chemojo sponges and even tourists do not know how the authenticity of the actual kemojo sponges is. 


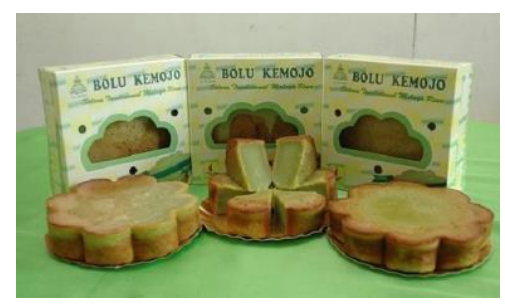

Figure 1. Kemojo Cake, which was taken from www.daerahkita.com in July 2021

Visiting an area, of course, tourists are looking for souvenirs or souvenirs that are famous in the area, such as one of the Bolu Kemojo stores, Gerai Al-Mahdi, not only in demand by tourists but also by the people of Pekanbaru. The production of chemojo cake at the Al-Mahdi outlet was originally done traditionally. The burning process uses charcoal and is done nonstop from 6 am to $7 \mathrm{pm}$, and only produces 10 pieces of kemojo sponge. The longer the kemojo cake business, Dinawati's Al-Mahdi outlet, is growing and orders are increasing every day. This makes him have to switch working methods, from traditional (using charcoal) to modern (using a gas oven).

Nowadays, there are many souvenir shops selling Kemojo sponge cake with a variety of flavors, shapes, and colors, while in Pekanbaru city today there are still people who use traditional processing methods using tangkring ovens with the help of charcoal as a top fire, but this is only for individual consumption and not for sale. Based on this, this preservation aims to maintain the authenticity of the kemojo cake and the changes and negative impacts caused by the existence of the kemojo cake today by tracing the history, materials and tools, the process of making and presenting the kemojo sponge as a form of preservation. This research can also be documented as a form of maintaining the authenticity of the sponge cake of the Riau Malay community.

The general purpose of this study is to find out one of the traditional Indonesian cakes "Bolu Kemojo" which has long existed among the ethnic Malays of Riau Province by writing, compiling information, and documenting in the form of photos and videos about "Bolu Kemojo" typical of Riau Malays, which will be discussed later. to bring back the existence of the original Kemojo sponge to the people of Riau Province and the people of Indonesia.

\section{METHODS}

This type of research uses a descriptive method with a qualitative approach in the form of a case study design. Basically this research focuses on the facts that are happening at this time, namely the many sellers of kemojo sponge in the market who have modified one of these traditional cakes, which is feared to make interest decline. society towards the original chemojo cake so that this also affects the threat of extinction of the kemojo sponge which comes from the ancestors of the Riau Malay people. Therefore, the preservation efforts carried out in this study are to find out how the history, manufacturing materials, processing tools, processing methods and steps for making the original kemojo sponge. The steps to be taken are as follows:

\subsection{Pre-Field Stage}

The pre-field stage is one of the stages carried out before going into the field, in other words preparing the entire design before going to the field, the activities that will be carried out at this stage are conducting guidance with supervisors, conducting literature studies, surveys, and preparing proposals. 


\subsection{Implementation Stage}

The implementation stage is a follow-up to the pre-field stage in the form of data collection and analysis by interviewing the informants related to this research. There is a possibility that the number of resource persons who have been selected in this study will increase, this is done so that the research can run in accordance with the formulation of the problem that has been determined by the researcher, and the achievement of the objectives of this study.

\subsection{Reporting Stage}

The reporting stage is carried out by compiling data from research results that have been obtained from the field, then the data that has been compiled is adjusted to the formulation of the problem and research objectives and will be made in the form of a systematic and clear report.

\section{RESULTS AND DISCUSSION}

The findings and discussion of this research will be presented in the form of interview results. Researchers will present research data in accordance with indicators that have been made based on previously designed guidelines. Respondents in this study consisted of one Bolu Kemojo expert, five Bolu Kemojo shops and one local community who made traditional Bolu Kemojo.

1. Dinawati, S.Ag, MM. Bolu Kemojo expert, owner of the AL-Mahdi Bolu Kemojo shop and also chairman of the Riau Catering Association.

2. Tengku Rahmi Fitri, Bolu Kemojo businessman, street vendor Bolu Kemojo (Chomojo Siak).

3. Ririn Nurma Yasmi, Bolu kemojo businessman, owner of the Donut Palace shop.

4. Syarifah Kemala, S.Pd. Bolu Kemojo businessman, Mama Nizam's Kitchen shop owner.

5. Syaripah Maysarah, Bolu Kemojo businessman, Bolu Kemojo business owner Tigo Boedjang.

6. Nurlela Sari, Bolu Kemojo business actor, owner of a souvenir shop for Bolu Kemojo Mimie.

7. Endang, S.Pd. The local community is the maker of Traditional Kemojo Bolu and the Owner of the Cikgu-Ala Village Cuisine Outlet, En.

The data obtained from interviews are in the form of informants' answers to statements that have been submitted by researchers with interview guides and carried out face-to-face directly which later data from the informants' answers will be presented in the form of excerpts from interviews. The next stage of the interview results will explain the respondents' answers that vary about the history of Bolu Kemojo, Bolu Kemojo business, and the traditional making of Bolu Kemojo which will later be able to answer the problem formulation of this research.

\subsection{Bolu Kemojo History Interview with Bolu Kemojo Experts}

Bolu Kemojo has existed since the days of the kingdom to be precise, the kingdom of Siak Sri Inderapura which is now located in the Riau province, Bolu Kemojo is a typical food of the Riau Malay community that must be present in traditional events or activities of the Malay community, the naming of Bolu Kemojo is obtained from the first two alternatives. is from a Cambodian royal servant of Siak, the second alternative is the shape of the side of this cake like frangipani flowers. Not all regencies in Riau produce Bolu kemojo, to be precise, there are 3 regencies out of 12 regencies in Riau province.

\subsection{Interview with Bolu Kemojo Business Actors}

The Bolu Kemojo business, named Chomojo siak, innovates or changes the typical Riau Malay food, namely Bolu Kemojo by making a small shape, but still shaped like a flower with 
additional flavor toppings on top including cheese, durian, chocolate, tiramisu and greentea. This Kemojo Bolu recipe sold by Chomojo Siak is obtained from a hereditary family that has existed for a long time.

Bolu Kemojo which is produced at the Istana Donut shop has a unique characteristic with the addition of aroma ingredients, namely adding spices in the Bolu Kemojo so that it has a fairly strong spice smell.

Kitchen Mama Nizam is a typical Siak gift shop that produces and sells original Bolu Kemojo but also innovates Bolu Kemojo by producing mini shapes with variant flavors, namely cheese, chocolate, durian, banana, and pumpkin. The original recipe was obtained from a family who had worked in the Siak kingdom, therefore the original royal kemojo sponge product was still sold at the Mama Nizam's Kitchen store.

Bolu Kemojo Tiga Boedjang is a home-based business that produces kemojo with an order system, so it doesn't produce every day. The kemojo products that are sold are original kemojo but also produce kemojo with a variety of flavors, namely red bean, durian, brown sugar, dates, and corn. Uniquely, Kemojo Tiga Boedjang has chemojo with brown sugar flavor which is specifically for diabetics, besides the flavor variant, there is also a modified chemojo shape with a mini shape and a heart shape.

Bolu Kemojo which is sold at the Bolu Kemojo Mimie Shop has been modified in the smaller kemojo shape, besides that Bolu Kemojo is also given flavor variants such as durian, corn, chocolate, and pumpkin but for flavor variants you must place an order in advance. The chemojos displayed in this shop are only chemojos with original flavors with mini shapes and original shapes in general.

Finally, the recipes and methods are discussed in the following. This is important to teach how to make the cake. The ingredients are $1 \mathrm{~kg}$ of flour, $1 \mathrm{~kg}$ of sugar, $1.50 \mathrm{~kg}$ of coconut cream, 10 eggs, 0.50 wrap of margarine, salt, pandan leaves, and spices (nutmeg, cinnamon, cumin, cloves). The way how to make are:

(i) We mix the flour with sugar, stir until evenly distributed.

(ii) We add coconut milk and chicken eggs.

(iii) We prepare the spices that have been finely ground and filtered.

(iv) We put the spice powder into the dough then add salt.

(v) We mash pandan leaves and take the juice.

(vi) We add pandan juice to the mixture and stir the mixture until it is well mixed.

(vii) If the dough is still too thick, we add more pandan juice.

(viii) After getting the right consistency, we add margarine to the dough, stir until the margarine breaks into small lumps.

(ix) We prepare a chemojo pan and grease it with margarine.

(x) We pour the chemojo batter into the pan and bake in the oven with top and bottom coals for 10-15 minutes.

The implications of this study are:

(i) From the results of the ongoing research process, the researchers found that the Bolu Kemojo sold in the market has changed with innovations and modifications that are tailored to the tastes of today's society.

(ii) The mini Bolu Kemojo shape is very much in demand by the public because it is more practical and the price is more affordable than the Original Kemojo Bolu, this is evidenced by the many Bolu Kemojo shops that sell Kemojo in mini form.

(iii) There are so many variants of Bolu Kemojo flavors ranging from chocolate, cheese, corn, brown sugar, and others, this will affect the loss of the original existence of Bolu Kemojo from the Malay community of Riau province. 
(iv) The traditional Kemojo cake does not have a definite measure and the equipment used is also very simple.

The recommendations of this study are:

(i) It is necessary to analyze the level of interest of the original Bolu Kemojo in the Malay community of Riau province so that Bolu Kemojo can survive and compete in business actors.

(ii) It is necessary to research Bolu Kemojo business actors to maintain Kemojo with the original variant, besides that the authenticity of this Kemojo is not lost and can continue to survive in the market.

(iii) It is necessary to do further research on the preservation of Bolu Kemojo as a snack at a traditional Malay event to know more about Bolu Kemojo in depth.

(iv) People who make Bolu Kemojo should maintain the characteristics of the original Kemojo and make Bolu Kemojo a habit at traditional and religious events.

\section{CONCLUSION}

Kemojo sponge cake has existed since the days of kingdoms such as the Siak kingdom which is still included in the province of Riau. This Kemojo Sponge cake used to be present only at certain events such as Malay traditional events, Eid days, and other great events, nowadays Kemojo sponge cakes are widely sold and easy to find, it is proven that there are many Kemojo sponge shops in the Regency or City, so everyone can eat Bolu Kemojo anywhere and anytime. The taste of the Kemojo sponge is very sweet, even in ancient times this cake could last a long time because of the high sugar content as a preservative, but nowadays, Kemojo cake is made with a taste that is not too sweet like in the past by adjusting to the tastes of the current generation.

Evidence that the existence of Bolu Kemojo in Riau province is strong can be proven from the number of business actors that have emerged, spread from cities to regencies. This creates innovations and modifications to the Kemojo Sponge Cake that has been made by business actors such as smaller flavors and shapes. Therefore, the preservation of Bolu Kemojo is carried out so that it does not disappear from business actors and the community, the preservation is carried out by remaking the Kemojo cake which has existed since ancient times with its authenticity together with one of the local villagers who know the original Bolu Kemojo recipe starting from the tools, materials, processing and packaging.

\section{AUTHORS' NOTE}

The authors declare that there is no conflict of interest regarding the publication of this article. Authors confirmed that the paper was free of plagiarism.

\section{REFERENCES}

Hartini, S. A., \& Swasty, W. (2018). Perancangan Logo Dan Kemasan Bolu Kemojo Monalisa. eProceedings of Art \& Design, 5(3), 1870-1877.

Kusumaningtiyas, A., Wibisono, B., and Kusnadi. (2013). Penggunaan istilah makanan dan jajanan tradisional pada masyarakat di kabupaten banyuwangi, 1(1), 1-9.

Ramadhani, D. A., and Mulyani, S. (2018). Pengaruh substitusi tepung terigu dengan tepung sagu terhadap tingkat kesukaan bolu kemojo. JPK: Jurnal Proteksi Kesehatan, 7(2), 6873.

Rosmayanti, R., Lasmanawati, E., and Nurani, A. S. (2019). Pelestarian "kue mayit" sebagai kue tradisional Garut. Media Pendidikan, Gizi, dan Kuliner, 8(2), 35-41. 